\title{
Interaksi Edukatif Guru dan Siswa Berdasarkan Tingkat Kemampuan dalam Pembelajaran Matematika di Kelas XI Pemasaran 1 SMK Negeri 1 Payakumbuh
}

\author{
Viola Brilyant Elka ${ }^{1}$, Nunu Burhanuddin ${ }^{2}$, dan Haida Fitri ${ }^{3}$ \\ ${ }^{1,2,3}$ Program studi pendidikan matematika, LAIN Bukittinggi \\ e-mail: : violaelka@yahoo.com
}

\begin{abstract}
ABSTRAK. Penelitian ini bertujuan untuk mengetahui interaksi edukatif guru dan siswa berdasarkan tingkat kemampuan dalam pembelajaran matematika. Tingkat kemampuan siswa dibagi menjadi 3 kategori, yaitu tingkat kemampuan tinggi, tingkat kemampuan sedang, dan tingkat kemampuan rendah. Teknik pengumpulan data adalah dengan wawancara, observasi, dan dokumentasi. Jenis penelitian yang digunakan adalah penelitian deskriptif kualitatif. Pengumpulan data dilakukan dengan observasi, wawancara, dan dokumentasi. Wawancara dilakukan bersama guru matematika dan 6 orang siswa yang dipilih berdasarkan tingkat kemampuannya. Analisis data dilakukan dengan pengumpulan data, reduksi data, penyajian data, dan penarikan kesimpulan. Pemeriksaan keabsahan data dilakukan dengan mengadakan triangulasi. Berdasarkan penelitian yang telah dilakukan diperoleh hasil bahwasanya di dalam proses pembelajaran, perhatian yang diberikan oleh guru matematika kepada siswa yang berkemampuan tinggi adalah dengan memberikan soal latihan yang lebih banyak dengan tingkat kesulitan yang lebih tinggi. Untuk siswa yang berkemampuan sedang, guru meminta bantuan kepada siswa berkemampuan tinggi untuk membantu mereka jika terjadi kesulitan disaat belajar dan mengerjakan tugas. Sedangkan untuk siswa yang berkemampuan rendah, guru matematika yang mengajarkan langsung ditempat duduk mereka masing-masing
\end{abstract}

Kata kunci: Interaksi Edukatif guru dan siswa, Tingkat Kemampuan Siswa dalam pembelajaran matematika.

\section{PENDAHULUAN}

Manusia pada dasarnya tidak lepas dari manusia lainnya hal ini sesaui defenisi menuru sardiman manusia adalah makhluk individu dan makhuk sosial (Sardiman A.M, 2012:1). Dalam hubungannya dengan manusia sebagai makhluk sosial, terkandung suatu maksud bahwa manusia bagaimanapun juga tidak dapat terlepas dari individu lain. Secara kodrati manusia akan selalu hidup bersama. Hidup bersama antar manusia akan berlangsung dalam berbagai bentuk komunikasi dan situasi. Dalam kehidupan semacam inilah terjadi interaksi.

Pada dunia pendidikan juga akan terjalin hubungan antara guru dan siswa yang ada di dalam proses pembelajaran. Hubungan itu dapat tercipta karna adanya rasa saling membutuhkan satu sama lain. Guru membutuhkan siswa untuk diajar dan siswa membutuhkan seorang guru untuk mengajarkan mereka. Dalam proses belajar mengajar tentu tidak akan terlepas dengan yang namanya interaksi antara guru dan siswa.

Interaksi edukatif adalah interaksi yang dengan sadar meletakkan tujuan untuk mengubah tingkah laku dan perbuatan seseorang (Syaiful Bahri Djamarah, 2012:11). Oleh karena itu, interaksi edukatif perlu dibedakan dari bentuk interaksi yang lain.

Adapun indikator yang digunakan dalam penelitian ini adalah ciri-ciri dari interaksi edukatif yaitu interaksi edukatif mempunyai tujuan, mempunyai prosedur yang direncanakan untuk mencapai tujuan, interaksi edukatif ditandai dengan penggarapan materi khusus, ditandai 
dengan aktivitas siswa, guru berperan sebagai pembimbing, interaksi edukatif membutuhkan disiplin, mempunyai batas waktu, dan diakhiri dengan evaluasi (Syaiful Bahri Djamarah, 2012:15 ).

Berdasarkan observasi yang peneliti lakukan di SMK Negeri 1 Payakumbuh pada kelas XI Pemasaran 1 tanggal 20 November - 24 November 2018 kepada guru dan siswa, menunjukkan bahwa dalam proses pembelajaran, interaksi antara guru dengan siswa sudah baik. Guru membuka pelajaran dengan membaca doa bersama dengan siswa, guru mereview pelajaran pada pertemuan sebelumnya, guru mengajarkan materi pembelajaran secara rinci dan menggunakan cara yang singkat. Setelah menerangkan materi pelajaran, guru memberikan latihan kepada siswa. Disaat siswa mengerjakan latihan, guru berkeliling kelas untuk melihat aktivitas siswa. Untuk siswa yang mendapat kesulitan dalam mengerjakan soal, guru langsung membantu siswa di tempat duduknya masing-masing. Dan bagi siswa yang cepat dalam mengerjakan soal, guru memintanya membantu temannya yang kesulitan. Permasalahan yang ditemukan adalah meskipun guru matematika berusaha memberikan perhatian kepada siswa, namun hasil belajar matematika siswa kelas XI Pemasaran 1 masih dikategorikan standar. Berdasarkan perhitungan, nilai rata-rata ulangan harian siswa kelas XI Pemasaran 1 adalah 76.

\section{METODE}

Jenis penelitian ini adalah penelitian desktiptif kualitatif untuk mendeskripsikan interaksi edukatif guru dan siswa berdasarkan tingkat kemampuan dalam pembelajaran matematika di kelas XI Pemasaran 1 SMK Negeri 1 Payakumbuh. Metode deskriptif kualitatif adalah suatu metode yang bertujuan untuk membuat deskripsi, gambaran atau lukisan secara sistematis, faktual, akurat mengenai sifat-sifat serta hubungan antara fenomena yang diselidiki. Subyek dalam penelitian ini adalah guru matematika yang mengajar di kelas XI Jurusan Pemasaran 1 dan 6 orang siswa dari kelas XI Pemasaran 1 yang dipilih berdasarkan tingkat kemampuan tinggi, sedang, dan rendah. Berikut adalah tabel pengelompokkan siswa berdasarkan tingkat kemampaun siswa ( Suharsimi Arikunto,1993:271)

Tabel 1.Kriteria Pengelompokkan Kemampuan siswa

\begin{tabular}{cc}
\hline Skor (S) & Kelompok \\
\hline$S \geq(\bar{X}+D S)$ & Atas \\
$(\bar{X}-D S)<S<(\bar{X}+D S)$ & Tengah \\
$S \leq(\bar{X}-D S)$ & Bawah \\
\hline
\end{tabular}

Ket: $\mathrm{S}=$ Skor

$\bar{X}=$ Rata-rata

DS $=$ Deviasi Standar

Tabel 2.Hasil Perhitungan Pengelompokkan Kemampuan siswa

\begin{tabular}{ccc} 
Skor (S) & Kelompok & Banyak siswa \\
\hline$S \geq 85,6$ & Atas & 2 orang \\
$66,4<S<85,6$ & Tengah & 25 orang \\
$S \leq 66,4$ & Bawah & 3 orang \\
\hline
\end{tabular}

Berdasarkan tabel 2 pengelompokkan kemampuan siswa diatas diperoleh dari 30 orang orang siswa di kelas XI Pemasaran 1, terdapat 2 orang siswa yang masuk kategori berkemampuan tinggi, 25 orang siswa yang masuk kategori berkemampuan sedang, dan 3 orang siswa masuk kategori berkemampuan rendah. Maka untuk siswa berkemampuan tinggi, peneliti memilih 2 orang siswa dengan nilai tertinggi, untuk siswa berkemampuan sedang, peneliti memilih 2 orang siswa dengan nilai terendah pada kelompok sedang, dan untuk siswa berkemampuan rendah, peneliti memilih 2 orang siswa dengan nilai terendah pada kelompok rendah. 
Menurut Lofland (Lexy J. Moleong,2009:157 ), bahwa sumber data utama dalam penelitian kualitatif ialah kata-kata dan tindakan, selebihnya adalah data tambahan seperti dokumen dan lain-lain. Sumber data dalam penelitian ini, diperoleh melalui hasil wawancara dengan guru matematika dan enam orang siswa dari kelas XI Pemasaran 1. Untuk observasi dilihat dari pelaksanaan pembelajaran di dalam kelas, dan untuk dokumentasi diperoleh dari dokumen atau arsip yang terdapat di lapangan dan foto.

Teknik pengumpulan data pada penelitian ini adalah dengan wawancara, observasi, dokumentasi. Wawancara yang dilakukan dalam penelitian ini adalah wawancara terstruktur dengan memakai pedoman wawancara yaitu indikator interaksi edukatif supaya wawancara yang dilakukan terarah dan tidak melenceng dari pedoman wawancara yang ada sehingga pedoman wawancara berfungsi sebagai pengendali supaya wawancara tidak kehilangan arah. Sebelum pedoman wawancara ini digunakan untuk mewawancarai subyek penelitian, maka dilakukan validasi terlebih dahulu. Pengamatan ini dilakukan langsung didalam kelas, sehingga dapat dilihat secara jelas tentang bagaimana interaksi edukatif guru dan siswa di kelas XI PM 1. Dalam penelitian ini dokumen yang digunakan oleh peneliti adalah nama-nama siswa kelas XI Pemasaran 1 nilai hasil ulangan harian, dan RPP yang digunakan oleh guru matematika dalam mengajar.

Analisis data yang digunakan adalah metode deskriptif analitik, yaitu mendeskripsikan data yang dikumpulkan berupa kata-kata, gambar, dan bukan angka. Data yang berasal dari naskah, wawancara, catatan lapangan, dokumen dan sebagainya, kemudian dideskripsikan sehingga dapat memberikan kejelasan terhadap kenyataan atau realitas (Sudarto,1997:66 ).

\section{HASIL DAN PEMBAHASAN}

\section{Interaksi Edukatif Mempunyai Tujuan}

\section{Menempatkan siswa sebagai pusat perhatian}

Perhatian yang diberikan oleh guru matematika berbeda-beda untuk setiap tingkat kemampuan. Untuk siswa yang berkemampuan tinggi ia akan lebih cepat mengerti dibandingkan teman-temannya yang lain, sehingga jika diulang-ulang terus ia akan merasa jenuh, jadi untuk siswa yang berkemampuan tinggi diberikan soal lebih banyak lagi, untuk siswa berkemampuan sedang ia akan belajar dengan siswa yang berkemampuan tinggi yang disebut dengan tutor sebaya. Tutor dapat menyesuaikan diri sepenuhnya dengan keadaan awal siswa dan kebutuhan siswa selama menjalani proses belajar. Meski demikian, guru juga memantau kerja siswa dengan mendatangi siswa yang sedang bediskusi tersebut. Selanjutnya untuk siswa yang berkemampuan rendah guru matematika langsung yang datang kemejanya dan menuntunnya dalam menganalisa soal.

Guru dituntut kesabarannya dalam mengahadapi peserta didik yang lambat belajar, karena ciri-ciri, sifat dan perilakunya selalu lambat. Dan juga perhatian yang diberikan oleh guru matematika untuk siswa berkemampuan rendah adalah ketika nilai ulangan mereka jauh dibawah KKM, guru matematika akan memanggil siswa tersebut diluar jam pelajaran. Siswa merasa senang jika diberi perhatian oleh gurunya baik secara verbal maupun nonverbal.

\section{Mempunyai Prosedur Yang Direncanakan Untuk Mencapai Tujuan}

\section{a. Ada prosedur atau langkah-langkah sistematik dan relevan}

Langkah-langkah pembelajaran yang dilakukan oleh guru matematika adalah untuk jam pelajaran pagi dimulai dengan bedoa dan membaca Al-Qur'an, absensi siswa, mengulang materi sebelumnya, masuk materi selanjutnya, setelah mengerjakan latihan dan 
diakhiri dengan penutup. Untuk jam pelajaran sore tidak membaca Al-Qur'an hanya membaca doa dalam hati saja.

\section{b. Membutuhkan prosedur dan desain yang berbeda-beda}

Guru matematika tidak memberikan desain pembelajaran yang berbeda-beda dalam setiap pertemuan.

\section{Interaksi Edukatif Ditandai Dengan Penggarapan Materi Khusus}

\section{a. Materi didesain sedemikian rupa}

Guru matematika mendesain materi semudah dan sesimpel mungkin untuk siswa. Guru matematika menerangkan mulai dari yang dasar ke tingkat kesulitan yang lebih tinggi. Karena siswa di kelas XI PM 1 terdiri dari kemampuan yang heterogen. Namun, masih saja ada siswa yang masih belum mengerti materi yang dijelaskan oleh guru matematika. Hal ini dikarenakan mereka lengah disaat guru sedang menerangkan pelajaran ditambah lagi dengan tingkat kemampuan mereka yang rendah.

\section{b. Materi disiapkan sebelum berlangsungnya interaksi edukatif}

Guru matematika mengajar dengan menggunakan bahan ajar yang dikirim lewat grup Whatsapp kelas. Jadi sehari atau dua hari sebelum proses pembelajaran dimulai, guru matematika telah mengirimkannya di grup. Ini bertujuan agar siswa dapat membaca terlebih dahulu materi yang akan dipelajari sebelum guru menjelaskan. Namun bagi siswa yang berkemampuan sedang dan rendah, cara ini menyulitkan mereka karena mereka malas untuk membaca dan sudah merasa putus asa bahwasanya mereka tidak akan mampu memahami tanpa dijelaskan oleh guru matematika.

\section{c. Penggunaan metode belajar yang bervariasi}

Guru matematika tidak menggunakan model pembelajaran yang bervariasi. Guru matematika menggunakan metode ceramah, tanya jawab, dan diskusi.

\section{d. Penggunaan metode mengajar sesuai dengan tujuan pembelajaran}

Dengan metode yang dipakai oleh guru matematika beliau mengatakan dapat mencapai tujuan pembelajaran.

\section{e. Penggunaan metode mengajar sesuai dengan siswa dengan berbagai tingkat \\ kemampuan}

Guru matematika menggunakan metode pembelajaran yang berbeda-beda berdasarkan tingkat kemampuan anak. Untuk siswa yang berkemapuan tinggi, guru matematika bisa hanya dengan menggunakan metode ceramah karena dengan metode ceramah mereka sudah bisa mengerti pelajaran dengan cepat. Untuk siswa yang berkemampuan sedang diberikan metode ceramah dan diskusi, karena selain dengan metode ceramah siswa yang berkemampuan sedang juga dapat berdiskusi dengan teman sebangku maupun dengan siswa yang berkemampuan tinggi. Sedangkan untuk siswa yang berkemampuan rendah, guru matematika menggunakan metode ceramah dan menuntun langsung kemeja siswa tersebut karena untuk siswa yang berkemampuan rendah agak sulit untuk menggunakan metode ceramah saja. 


\section{f. Menggunakan media pembelajaran}

Guru matematika menggunakan media pembelajaran berupa HP, papan tulis, spidol dan penghapus papan. Untuk media seperti busur, jangka, rol, dan lain-lain digunakan tergantung materi yang akan dipelajari. Sesekali dalam proses pembelajaran guru matematika pernah memakai media infocus dan tab untuk mengajar, tapi itu sangat jarang disebabkan karena keterbatasan infocus di sekolah.

\section{Ditandai Dengan Aktivitas Siswa}

a. Guru berusaha memancing siswa untuk ikut serta dan aktif baik secara fisik maupun mental dalam proses pembelajaran

Guru matematika memancimg siswa untuk berperan aktif didalam proses pembelajaran dengan cara menegur, memberikan pertanyaan kepada siswa, dan meminta siswa menjawab soal dipapan tulis.

\section{b. Guru memberikan reward kepada siswa}

Guru memberikan reward kepada siswa berupa point tambah apabila siswa mampu mengerjakan soal yang ada dipapan tulis dengan benar.

\section{Guru Berperan Sebagai Pembimbing}

\section{a. Guru berusaha menghidupkan dan memberikan motivasi}

Guru memberikan motivasi kepada siswa dalam bentuk nasehat dengan cara mengingatkan mereka betapa orang tua mereka telah susah untuk membiayai sekolah mereka, untuk itu jangan kecewakan orang tua, belajarlah dengan bersungguh-sungguh.

\section{b. Guru memberikan bimbingan sesuai dengan tingkat kemampuan siswa}

Guru memberikan bimbingan kepada siswa berdasarkan tingkat kemampuannya. Bagi siswa yang berkemampuan tinggi dan sedang, guru memberikan bimbingan kepada mereka dengan bentuk bimbingan tutor sebaya. Siswa yang berkemampuan tinggi, membatu siswa yang berkemampuan sedang proses pembelajaran. Sedangkan untuk siswa yang berkemampuan rendah, guru langsung yang harus menuntunnya dalam menganalisa dan menjawab soal.

\section{c. Guru mengontrol dan mengendalikan kelas}

Cara guru mengontrol dan mengendalikan kelas dengan cara memberi teguran dan nasehat apabila siswa sudah mulai ribut dan tidak fokus dalam belajar.

\section{Interaksi Edukatif Membutuhkan Disiplin}

\section{> Guru menegakkan kedisiplinan kepada siswa}

Pada pertemuan pertama diawal semester guru matematika sudah membuat kontrak belajar dengan siswa berupa tata tertib selama jam pelajaran dengan beliau. Dan itu dibuat dibuku catatan dan ditandatangani oleh siswa tersebut dan guru matematika. Bagi siswa yang melanggar dan tidak patuh terhadap peraturan akan diberikan sanksi, yang mana sanksi tersebut tidak boleh merugikan siswa dan harus bersifat mendidik. 


\section{Mempunyai Batas Waktu}

\section{$>$ Guru memberikan batas waktu dalam proses interaksi edukatif}

Guru memberikan batas waktu kepada siswa dalam hal membuat catatan dan latihan. Dalam pembagian waktunya, guru matematika sudah memilah-milah waktu berdasarkan langkah-langkah pembelajaran agar bisa tercapainya tujuan pembelajaran yang diharapkan.

\section{Diakhiri Dengan Evaluasi}

\section{a. Guru menggunakan seperangkat penggali data}

Bentuk evaluasi yang diberikan oleh guru matematika yaitu dengan memberikan latihan kepada siswa, memberikan kuis jika dibutuhkan, dan mengadakan ulangan harian setelah menyelesaikan $1 \mathrm{KD}$.

\section{b. Memungkinkan guru menilai aktivitas/pengalaman yang didapat siswa}

Aktivitas siswa yang dinilai oleh guru matematika berupa aktivitas selama guru menerangkan, disaat diskusi, aktivitas siswa dalam mencatat dan dalam membuat latihan.

\section{KESIMPULAN}

Berdasarkan hasil penelitian yang telah dilakukan oleh peneliti di kelas XI Jurusan Pemasaran 1 SMK N 1 Payakumbuh yang mengkaji tentang interaksi edukatif guru dan siswa berdasarkan tingkat kemampuan dalam pembelajaran matematika, dapat disimpulkan bahwasanya guru matematika memberikan perhatian sesuai dengan tingkat kemampuan siswa.

Guru matematika memberikan bahan ajar kepada siswa dalam bentuk soft copy file yang dikirim melalui grup Whatsapp kelas XI PM 1. Guru matematika berkeliling kelas untuk melihat aktivitas siswa. Untuk siswa yang berkemampuan rendah atau yang sulit menerima pelajaran, guru matematika turun langsung mengajarkan ke tempat duduk siswa. Sedangkan untuk siswa yang berkemampuan tinggi dan sedang, guru matematika menerapkan cara belajar tutor sebaya.

Guru matematika memberikan soal yang lebih banyak dengan tingkat kesulitan yang lebih tinggi kepada siswa yang berkemampuan tinggi dan sedang. Apabila siswa berkemampuan sedang mengalami kesulitan, guru meminta siswa yang pintar membantu teman-temannya.

Dalam menegakkan kedisiplinan, guru matematika menerapkan aturan yang harus dipatuhi selama pelajaran matematika dan bagi siswa yang melanggar akan diberikan sanksi. Setelah menjelaskan materi pelajaran, guru matematika memberikan latihan kepada siswa. Setelah satu KD (Kompetensi Dasar) guru matematika mengadakan ulangan harian. Bagi siswa yang mendapatkan nilai dibawah KKM maka akan diberikan remedial dan bagi siswa yang mendapatkan nilai KKM ataupun diatas KKM diberikan pengayaan. Kemudian diakhir pelajaran guru matematika bersama siswa mengambil kesimpulan tentang pelajaran hari itu.

\section{SARAN}

Untuk mengurangi angka remedial siswa dalam pembelajaran matematika, sebaiknya ada komunikasi yang intensif antara guru dan siswa, terutama bagi siswa yang berkemampuan rendah agar guru bisa mengetahui apa kesulitan yang dialami oleh siswa sehingga sulit dalam menerima pelajaran yang diberikan. 


\section{UCAPAN TERIMA KASIH}

Ucapan terimakasih kepada dosen pembimbing yang membantu dalam pembuatan artikel ini dan guru matematika beserta siswa kelas XI Jurusan Pemasaran 1 SMK Negeri 1 Payakumbuh sebagaii subjek dalam penelitian ini.

\section{REFERENSI}

A.M, Sardiman. 2012. Interaksi dan Motivasi Belajar Mengajar.Jakarta:PT. RajaGrafindo Persada Arikunto, Suharsimi. 1993. Dasar-Dasar Evaluasi Pendidikan. Jakarta:Bumi Aksara Djamarah, Syaiful Bahri. 2012. Guru dan Anak Didik Dalam Interaksi Edukatif. Jakarta:PT.Rineka Cipta

Moleong, Lexy J. 1995. Metodologi Penelitian Kualitatif. Bandung:PT.Remaja Rosdakarya. Cet ke-30

Sudarto. 1997. Metodolgi Penelitian Filsafat. Jakarta:RajaGrafindo Persada 